\title{
Evaluation of Some Processing Characteristics of Cultivated Guava Clones
}

\author{
A. J. Rodriguez and L. M. Iguina de George ${ }^{1}$
}

INTRODUCTION

The food industry of Puerto Rico has depended mainly on wild guava to satisfy the ever-increasing market demand for their guava products. Even though the nectars prepared from wild fruit require the use of artificial color and have a short shelf-life at room temperature, the relative abundance of wild fruit and the lack of commerical orchards of selected varieties have favored its almost exclusive use as raw material in the processing of guava products.

The Agricultural Experiment Station has been trying to develop guava varieties with better processing characteristics than the wild fruit, i.e., with pink or red color pulp, adequate acidity level, high solid and pectin content, and better suited for the production of nectars of extended shelf-life. The availability of selected guava clones of different characteristics has made it possible to study the effect of clonal characteristics on the yield and shelflife of guava nectar.

\section{MATERIAL AND METHODS}

A preliminary selection was made among 141 clones from Fortuna and Gurabo Substations because of the relatively large number of clones available for the study. The fruits were classified into groups, according to their soluble solid content, $\mathrm{pH}$, and pulp color, thus limiting the number of composite samples of fruit clones with similar characteristics. Only red- or or pink-pulp guavas in the $\mathrm{pH}$ range of 2.7 to 3.7 were selected to avoid use of additives such as citric acid and certified food color dyes that could mask the natural fruit quality in the product. Based on these criteria, 11 composite samples were submitted to chemical analyses and used in the preparation of nectars. For the chemical analyses, the pulp and shells were homogenized in a blender after discarding the seeds, and the vitamin- $C$ content, percent reducing and total sugars, percent total acidity, and percent refractometric solids, were determined in the homogenates.

${ }^{1}$ Chemical Engineer and Assistant Food Technologist, respectively, Food Technology Laboratory, Agricultural Experiment Station, Mayagüez Campus, University of Puerto Rico, P.R. The authors express their appreciation to J. R. Benero, Associate Chemist, L. A. Lefebre de González, Assistant Food Technologist, I. Hernández, Assistant Chemical Engineer, A. R. Sandoval and A. B. Rivera, former Research Assistants, for their helpful cooperation in the performance of this study, and $\mathrm{W}$. Pennock, Horticulturist, for supplying the fruit samples. 
Vitamin $\mathrm{C}$ was determined by the Ballantine method (1)2, refractometric solids with the Abbe-type refractometer and expressed as degree Brix, and $\mathrm{pH}$ by the A.O.A.C. glass electrode method (3). Total titratable acidity as citric acid was determined by potentiometric titration with $0.1 \mathrm{~N} \mathrm{NaOH}$ standard solution ( $(3)$, and reducing and total sugars by the Lane and Eynon method (8).

Soluble pectin in the guava groups was measured in terms of the relative viscosity of the water extracts. Fruit samples of $250 \mathrm{~g}$. were cut into small pieces and boiled in $250 \mathrm{~g}$. of water for 30 minutes. After boiling, water was added to restore the sample to the original weight of $500 \mathrm{~g}$. The extracts were filtered through glass wool and cooled to $28^{\circ} \mathrm{C}$. $\left(82.4^{\circ} \mathrm{F}\right.$.). The relative viscosity of the extracts was determined by dividing the time of flow of the extracts by the time of flow of distilled water through a calibrated pipet at a constant temperature of $28^{\circ} \mathrm{C}$. $\left(82.4^{\circ} \mathrm{F}\right.$.).

Pulp yields were calculated from the weight of pulp obtained in a Langsenkamp ${ }^{3}$ Laboratory Paddle Pulper using a 0.033-inch screen. The yields are expressed as pounds of pulp per 100 pounds of fruit.

Nectars were prepared from each of the 11 composite samples by the procedure described by Sánchez-Nieva (5). The samples were pasteurized at $190^{\circ} \mathrm{F} .\left(87.8^{\circ} \mathrm{C}\right.$.), and packed in 8-ounce plain tin cans and stored at $85^{\circ} \mathrm{F}$. $\left(29.4^{\circ} \mathrm{C}\right.$.). The quality of the canned nectars was evaluated organoleptically using a 9-point hedonic scale (4) when fresh and after 9 months of storage at $85^{\circ} \mathrm{F}$. $\left(29.4^{\circ} \mathrm{C}\right.$.). A similar evaluation was carried out with a canned wild guava nectar used as reference sample.

A second evaluation was conducted with 13 clones from the Fortuna Substation. Each clone was analyzed and nectars were prepared for an organoleptic evaluation as previously described, except that fruits were washed and weighed and average-shell thickness and seed cavity were determined for each selection. Pulp yield was determined from the weight of the pulp obtained through the 0.020 -inch screen of the paddle finisher. Nectars were prepared from each individual fruit clone by diluting the pulps to 25-percent insoluble fruit solids content instead of diluting to constant viscosity.

\section{RESULTS AND DISCUSSION}

Data from the chemical analyses and the yields of pulp and nectar of the 11 composite guava samples is presented in table 1 . Total acidity varied

2 Numbers in parentheses refer to Literature Cited p. 52.

Trade names are used in this publication solely for the purpose of providing specific information. Mention of a trade name does not constitute a guarantee or warranty of the equipment by the Agricultural Experiment Station of the University of Puerto Rico or an endorsement over other equipment not mentioned. 
from 0.97 to 1.87 percent, refractometric solids from 8.8 to 10.8 degree Brix, total sugars ranged from 4.82 to 9.38 percent, and the vitamin C content from 22.42 to $129.69 \mathrm{mg}$. per $100 \mathrm{~g}$. of pulp. Total acidity of the selected pulps studied was higher than that of the wild fruit. The percent of soluble solids (degrees Brix) of the wild guava sample was within the range of values obtained for the cultivated fruits. A similar relationship was observed among the results of the total sugars. The percentages of reducing sugars, on the other hand, were lower for the selected fruit than for the wild fruit. Seven of the 11 clonal samples had a higher vitamin $\mathrm{C}$ content than the control.

TABLE 1.-Chemical analyses and pulp yield from 11 composite clonal samples and a wild fruit sample used as control

\begin{tabular}{|c|c|c|c|c|c|c|c|c|c|}
\hline Sample & $\begin{array}{c}\text { Neclar } \\
\text { yield }\end{array}$ & Pulp yield" & $\begin{array}{l}\text { Relative } \\
\text { viscosity }\end{array}$ & $p H 1: 1$ & $\begin{array}{c}\text { Tolal } \\
\text { acidity }\end{array}$ & Brix & $\begin{array}{l}\text { Total } \\
\text { sugar }\end{array}$ & $\begin{array}{l}\text { Reducing } \\
\text { sugar }\end{array}$ & $\underset{C}{\text { Vilamin }}$ \\
\hline & $\begin{array}{l}\text { Gal./100 } \\
\text { bb. } / \text { resil }\end{array}$ & $\begin{array}{l}\text { Lb. } / 100 \\
\text { lb. fruil }\end{array}$ & & & Percent & Degree & Percent & Percent & $\begin{array}{l}M 9 . / \\
100 \mathrm{~g} .\end{array}$ \\
\hline Control & 33.2 & 80.50 & 1.385 & 3.47 & 0.97 & 9.2 & 6.37 & 5.55 & 32.59 \\
\hline 1 & 31.5 & 89.92 & 1.345 & 3.11 & 1.66 & 9.6 & 6.05 & 3.39 & 24.59 \\
\hline 2 & 31.4 & 87.98 & - & 3.12 & 1.47 & 8.8 & 4.82 & 2.93 & 22.42 \\
\hline 3 & 31.2 & 93.14 & 1.495 & 3.03 & 1.87 & 10.8 & 6.68 & 4.38 & 85.41 \\
\hline 4 & 30.6 & 91.49 & 1.350 & 3.48 & 1.28 & 9.8 & 7.15 & 4.20 & 55.62 \\
\hline 5 & 30.4 & 88.89 & 1.440 & 3.08 & 1.61 & 10.4 & 6.45 & 4.91 & 53.20 \\
\hline 6 & 28.9 & 91.43 & 1.336 & 3.16 & 1.37 & 10.0 & 6.01 & 4.29 & 43.01 \\
\hline 7 & 28.8 & 91.55 & 1.245 & 3.34 & 1.17 & 9.3 & 5.98 & 3.90 & 43.55 \\
\hline 8 & 26.9 & 84.87 & 1.255 & 3.15 & 1.03 & 10.0 & 9.38 & 3.70 & 129.69 \\
\hline 9 & 25.0 & 80.00 & 1.325 & 3.35 & 1.28 & 9.6 & 6.37 & 4.58 & 69.22 \\
\hline 10 & 23.0 & 94.44 & 1.255 & 3.34 & .97 & 9.0 & 5.21 & 2.99 & 31.78 \\
\hline 11 & 21.5 & 92.36 & 1.097 & 3.42 & 1.10 & 9.1 & 5.40 & 4.40 & 30.03 \\
\hline
\end{tabular}

1 Pulp finished through 0.033 -inch screen.

The highest yield of nectar was obtained from wild fruit. Five of the cultivated clonal samples gave yields of nectar higher than 30 gallons while six of the samples gave yields of nectar lower than 28.9 gallons. From the standpoint of yields the first five groups of clones listed in table 1 are superior to the others and would be more suitable for industrial use.

The yield of pulp ranged from 80.00 to 94.44 pounds per hundredweight of fruit. With the exception of sample 9, all the cultivated samples had a higher yield of pulp than the wild fruit. It should be noted from the data in table 1 that the pulp yields bear no direct relationship to the yield of nectar. This is due to the fact that in the preparation of the nectars the pulp was diluted to a constant viscosity value. Yields of nectars therefore are dependent on the pectin content of the pulp which directly affects the viscosity of the pulp dispersions and not on pulp content. 
Nectar yield figures apparently indicate a higher soluble pectin content in the wild fruit than in any of the guava clones tested. It should be noted that the values for the relative viscosities of the water extracts of some of the cultivated fruits were as high or even higher than those obtained for the wild guava. The differences among the values of the relative viscosities of the water extracts in table 1 might be due to differences in the degree of maturity and ripeness of the fruits used for the extractions. The stage of

TABLE 2.-Hedonic scale values obtained in the organoleptic evaluation of nectar prepared from composite guava clonal samples and a wild guava nectar used as reference

\begin{tabular}{cccc}
\hline \multirow{2}{*}{ Group } & \multirow{2}{*}{ Sample } & \multicolumn{2}{c}{ Bedonic ratings } \\
\cline { 3 - 4 } & & Presh & 9 months \\
\hline \multirow{2}{*}{ A } & 6 & 6.4 & 6.3 \\
& 3 & 6.6 & 4.8 \\
& 5 & 6.9 & 6.1 \\
& 1 & 7.4 & 6.7 \\
B & Control & 5.8 & 4.6 \\
\hline & 9 & 6.6 & 7.0 \\
& 4 & 6.2 & 7.1 \\
C & 10 & 7.0 & 7.1 \\
& Control & 5.7 & 5.5 \\
\hline & 8 & 6.9 & 5.7 \\
& 7 & 7.0 & 6.3 \\
D & 2 & 6.7 & 5.0 \\
& Control & 7.0 & 4.4 \\
\hline & 11 & 7.1 & 6.9 \\
& Control & 6.8 & 6.9 \\
\hline
\end{tabular}

1 Hedonic ratings are based on a 9-point hedonic scale in which 9 stands for like extremely; 8 , like very much; 7 , like moderately; 6 , like slightly; 5 , neither like nor dislike; and 1, dislike extremely.

ripeness indicates whether or not the fruits are at their optimum pectin content. In the evaluation of guava clones for nectar processing the viscosity of the water extracts as a measure of pectin content is of no signifcance unless the fruit samples are at a comparable stage of maturity.

The results of the organoleptic evaluation of the nectar samples when fresh and 9 months later are presented in table 2 . The nectars are grouped in the table according to the batches that were prepared in 1 day. For each group of batches, a control was similarly processed using wild fruit. In group A in table 2, samples 6, 5, and 1 changed less in storage and showed a better stable quality than the control. All clonal samples in group B were 
rated higher at the end of the 9-month storage period than when fresh. The data for this group showed that samples kept their quality at a fairly high level during the whole storage period at $85^{\circ} \mathrm{F}$. $\left(29.4^{\circ} \mathrm{C}\right.$.). Sample 10 in group B represents a composite of 12 different guava clones. It obtained the highest score in the tasting evaluation and produced the highest yield of pulp among all the samples under comparison. In group $\mathrm{C}$, the control underwent the greatest change during the storage period. In the last group, the control had better keeping qualities than sample 11. Of the 11 nectar samples prepared from cultivated fruit, 9 showed better stability during storage than the controls.

The results obtained from the first stage of the work led to the preliminary appraisal of the processing characteristics of the guava samples studied. The evaluation of the samples not only provided information on the keeping quality of the fruit nectars, but it also furnished data on pulp and nectar yield. Although the information collected was valuable for prescreening the guava varieties, it was not sufficient to ascertain the processing behavior of individual fruit selections.

A second set of tests were conducted with individual guava clones. Table 3 shows the data on chemical analyses and pulp yields from 13 selected guava samples and a wild fruit control. A large variation in pulp yields was observed among the fruit samples studied. Information on the average weight, diameter, shell thickness, average fruit cavity, and pulp, seed and shell percent is also presented in table 3 . In general, the cultivated guavas in our study were larger, weighed more, contained more edible pulp and shell, and contained fewer seeds than the wild guavas.

Chemical analyses of the fruit samples showed the following results: Refractometric solids ranged from 6.0 to 9.4 degree Brix, $\mathrm{pH}$ from 3.21 to 3.85 , and total acidity varied from 0.55 to 1.70 percent. The vitamin $\mathrm{C}$ content for the cultivated fruits varied from 20.31 to $78.96 \mathrm{mg}$. per $100 \mathrm{~g}$., while a higher value of $91.99 \mathrm{mg}$. per $100 \mathrm{~g}$. was obtained for the wild gua: :a.

In the preparation of the nectars from individual clones, the pulp was diluted to a fixed soluble fruit solid content of 25 percent. This change in the procedure for nectar preparation was made because the Proposed Standards of Identity for Canned Fruit and Fruit Juices (2) specify that guava nectars should contain no less than 25 percent fruit ingredient. The data in table 3 shows that 11 of 13 clones gave higher yields of nectar than the wild fruit. Because the pulp was diluted to a constant solid content and not to viscosity to obtain the nectar consistency, the higher yields of nectar result from the higher pulp content in the cultivated clones.

The results of the organoleptic evaluation of the nectars from individual guava clones, and a reference nectar prepared from wild guavas, are presented in table 4. The samples were appraised using a 9-point hedonic scale 
TABLE 3.-Chemical analyses and pulp yields from 19 single clones and a wild fruit sample used as control.

\begin{tabular}{|c|c|c|c|c|c|c|c|c|c|c|c|c|c|}
\hline Sample & Nedar yield & Pulp yield & $\begin{array}{l}\text { Average } \\
\text { weight }\end{array}$ & $\begin{array}{c}\text { Aver- } \\
\text { agg } \\
\text { diam- } \\
\text { eler }\end{array}$ & $\begin{array}{c}\text { Aver- } \\
\text { age } \\
\text { shell } \\
\text { thick- } \\
\text { ness }\end{array}$ & $\begin{array}{l}\text { Aver- } \\
\text { age } \\
\text { capily } \\
\text { diam- } \\
\text { eler }\end{array}$ & $\begin{array}{l}\text { Agerage } \\
\text { shell }\end{array}$ & $\begin{array}{c}\text { Average } \\
\text { pulpp }\end{array}$ & $\begin{array}{l}\text { Average } \\
\text { seed }\end{array}$ & $p H$ & $\begin{array}{c}\text { Tolol } \\
\text { ocidity }\end{array}$ & Brix & $\underset{C}{\text { Vilamin }}$ \\
\hline & Gal./100 lb. fruil & $L b . / 100 \mathrm{lb}$. fruit & Grams & Inches & Inehes & Inches & Percent & Percent & Percent & & Percent & Degree & $M g . / 100 \mathrm{~g}$. \\
\hline \multicolumn{14}{|l|}{ Wild guava } \\
\hline (control) & 28.67 & 66.50 & 36.2 & 1.5 & 0.2 & 1.1 & 49.5 & 40.4 & 10.1 & 3.80 & 0.55 & 8.2 & 91.99 \\
\hline $57-6-143$ & 33.40 & 78.49 & 77.4 & 2.0 & .3 & 1.4 & 67.4 & 27.8 & 4.8 & 3.73 & 1.08 & 9.0 & 40.21 \\
\hline $57-2-142$ & 33.21 & 73.09 & 68.8 & 2.0 & .3 & 1.4 & 65.2 & 28.6 & 6.2 & 3.66 & .96 & 6.4 & 33.32 \\
\hline $57-8-141$ & 32.20 & 79.22 & 76.8 & 2.1 & .3 & 1.5 & 66.7 & 36.0 & 3.3 & 3.35 & 1.46 & 8.8 & 48.02 \\
\hline $57-4-30$ & 32.16 & 75.05 & 91.0 & 2.1 & .3 & 1.5 & 68.8 & 23.1 & 8.1 & 3.30 & 1.42 & 6.0 & 27.20 \\
\hline 57-9-114 & 31.87 & 77.18 & 84.5 & 2.0 & .3 & 1.4 & 68.8 & 24.7 & 6.5 & 3.60 & 1.06 & 8.8 & 46.97 \\
\hline Trujillo 2 & 31.49 & 73.32 & 112.9 & 2.4 & .3 & 1.8 & 65.6 & 30.6 & 4.8 & 3.45 & 1.70 & 8.4 & 31.04 \\
\hline D-13 & 31.26 & 78.54 & 87.7 & 2.2 & .5 & 1.2 & 75.6 & 22.0 & 2.3 & 3.30 & 1.36 & 6.4 & 62.50 \\
\hline D-20 & 30.91 & 72.80 & 95.7 & 2.2 & .4 & 1.4 & 72.3 & 24.3 & 3.4 & 3.21 & 1.46 & 6.4 & 20.31 \\
\hline $57-4-120$ & 30.87 & 71.68 & 102.5 & 2.2 & .4 & 1.4 & 68.7 & 28.0 & 3.3 & 3.30 & 1.48 & 8.4 & 78.96 \\
\hline $57-2-51$ & 29.45 & 71.29 & 69.1 & 2.0 & .3 & 1.4 & 60.9 & 32.3 & 6.8 & 3.46 & 1.16 & 6.4 & 40.43 \\
\hline 58-3-71 & 29.30 & 82.39 & 72.5 & 1.9 & .3 & 1.3 & 71.8 & 24.6 & 3.6 & 3.85 & .85 & 8.0 & 22.92 \\
\hline $58-4-45$ & 27.53 & 69.44 & 81.6 & 2.1 & .3 & 1.5 & 65.2 & 28.1 & 6.7 & 3.27 & 1.29 & 9.4 & 50.12 \\
\hline $57-10-139$ & 26.99 & 73.53 & 109.5 & 2.2 & .4 & 1.4 & 70.5 & 26.1 & 3.4 & 3.70 & - & 7.6 & 33.92 \\
\hline
\end{tabular}


at 3-month intervals during a 9-month period. Clones 57-9-114 (Rico 18), 58-3-71 (Rico 13), 57-4-30 (Rico 21), 57-2-142 (Rico 19), 57-2-51 (Rico 20), D-13 (Rico 4), and Trujillo 2 (Rico 2) were rated as high or even higher than the wild fruit control at the end of the 9-month storage period at $85^{\circ} \mathrm{F}$. $\left(29.4^{\circ}\right.$ C.). Three of the samples, i.e., clones 57-9-114 (Rico 18) 57-2-142

TABLE 4.-Hedonic scale values obtained in the organoleptic evaluation of nectar samples prepared from individual guava clones and a wild guava nectar used as reference

\begin{tabular}{|c|c|c|c|c|c|}
\hline \multirow{2}{*}{ Grous } & \multirow{2}{*}{ Sample number } & \multicolumn{4}{|c|}{ Bedonic ratings at different storage intervalst } \\
\hline & & Presh & 3 months & 6 months & 2 months \\
\hline \multirow[t]{3}{*}{ A } & Control & 6.7 & 7.0 & 5.9 & 6.7 \\
\hline & $58-4-45$ & 7.2 & 6.1 & 5.7 & 6.3 \\
\hline & $57-6-143$ & 6.0 & 5.3 & 5.6 & 5.4 \\
\hline \multirow[t]{4}{*}{$\mathbf{B}$} & Control & 7.2 & 7.3 & 6.5 & 6.2 \\
\hline & $57-10-139$ & 7.1 & 6.3 & 6.1 & 5.9 \\
\hline & $57-9-114$ & 7.5 & 6.9 & 6.6 & 7.1 \\
\hline & 58-3-71 & 7.4 & 6.4 & 5.8 & 6.4 \\
\hline \multirow[t]{4}{*}{$\mathbf{C}$} & Control & 7.6 & 6.9 & 6.7 & 6.3 \\
\hline & $57-4-120$ & 6.8 & 6.7 & 6.5 & 5.8 \\
\hline & $57-4-30$ & 7.2 & 5.6 & 6.1 & 6.4 \\
\hline & $57-2-142$ & 7.4 & 6.6 & 6.9 & 7.5 \\
\hline \multirow[t]{4}{*}{ D } & Control & 7.0 & 6.8 & 5.9 & 7.0 \\
\hline & $57-8-141$ & 6.2 & 5.4 & 6.5 & 5.5 \\
\hline & $57-2-51$ & 7.2 & 6.8 & 6.9 & 7.1 \\
\hline & D-20 & 7.2 & 5.9 & 6.9 & 6.6 \\
\hline \multirow[t]{3}{*}{$\mathbf{E}$} & Control & 7.7 & 6.5 & 6.4 & 6.1 \\
\hline & D-13 & 7.2 & 6.8 & 6.8 & 6.7 \\
\hline & Trujillo 2 & 7.6 & 7.0 & 7.2 & 6.8 \\
\hline
\end{tabular}

1 Hedonic ratings are based on a 9-point hedonic scale in which 9 stands for like extremely; 8 , like very much; 7 , like moderately; 6 , like slightly; 5 , neither like nor dislike; and 1, dislike extremely.

(Rico 19), and 57-2-51 (Rico 20) were rated in the range of 7.1 to 7.5, thus showing superior keeping quality than the wild fruit control. Clone 57-2-142 (Rico 19) rated highest in flavor quality and also produced the highest nectar yield among all the promising varieties.

\section{SUMMARY}

An evaluation of the processing characteristics of the fruit of cultivated guava clones was conducted in a two-stage study. The first stage consisted in pre-screening the cultivated clones using the percent soluble solids, $\mathrm{pH}$, and color of the fruit pulp as criteria for selecting and combining the clones 
into representative samples. Eleven composite clonal samples were compared against a wild-fruit control. Pulp and nectar yields were determined and chemical analyses performed on each of the samples. Viscosity was used as a criterion for diluting the fruit pulps to nectar consistency. The canned nectar samples were appraised using a 9-point hedonic scale for scoring purposes. Nine of the 11 samples examined showed better stability during storage $85^{\circ} \mathrm{F}$. $\left(29.4^{\circ} \mathrm{C}\right.$.) than the control. Composite sample number 10 received the highest score and changed less in the 9-month storage period than other samples under study, also produced the highest pulp yield.

In the second stage of the study, an individual evaluation was conducted on each of 13 new guava clones and a wild-fruit control. Pulp and nectar yields and chemical analyses were performed on each fruit sample. Pulp dilutions for nectar preparation were based on solid content rather than on viscosity. Samples were evaluated organoleptically using a 9-point hedonic scale. The keeping quality of seven of the cultivated guava clones appeared comparable to that of the wild fruit. Three of the samples, i.e., clones 57-9-114 (Rico 18), 57-2-142 (Rico 19), and 57-2-51 (Rico 20), were rated higher than the control. Clone number 57-2-142 (Rico 19) scored highest in the quality evaluation of 9 -month storage at $85^{\circ} \mathrm{F}$. ( $29.4^{\circ} \mathrm{C}$.). This clone also produced the second highest nectar yield among the 13 clones under evaluation and was superior to the wild-fruit control.

\section{RESUMEN}

Se evaluaron en dos etapas las características de la fruta de algunos clones de guayaba para la elaboración, y asi determinar su utilidad para fines industriales. El trabajo se hizo en dos etapas. En la primera etapa, el $\mathrm{pH}$, el porcentaje de sólidos solubles y el color de la pulpa fueron los criterios que se usaron para seleccionar y combinar los clones en muestras representativas. Se utilizaron 11 muestras mixtas, cada una de las cuales se comparó con un control preparado de fruta silvestre. Mediante el análisis químico, se determinó el contenido de vitamina $\mathrm{C}$, el porcentaje de azúcares totales y reductoras, el $\mathrm{pH}$, el porcentaje de sólidos solubles, el porcentaje de acidez total, la viscosidad relativa de los extractos, el porcentaje de pulpa utilizable y el rendimiento de néctar de cada una de las muestras. Las muestras de néctares se evaluaron según una escala hedónica de 9 puntos. Nueve de las 11 muestras examinadas demostraron tener más establidad que la muestra control durante el almacenamiento a $85^{\circ} \mathrm{F}$. $\left(29.4^{\circ} \mathrm{C}\right.$.). El néctar correspondiente a la muestra mixta No. 10 recibió la calificación más alta y sufrió menos alteración que las demás muestras durante el almacenamiento. También produjo el mayor rendimiento de pulpa de todas las muestras estudiadas.

La segunda etapa del estudio consistió en la evaluación individual de cada uno de los 13 nuevos clones que se compararon con la guayaba sil- 
vestre. Se determinó el rendimiento de pulpa y de néctar de cada uno. Las pulpas se diluyeron a una consistencia de néctar, usándose el contenido de sólidos como el criterio para la dilución. Los néctares se sometieron a una evaluación organoléptica usándose la escala hedónica de 9 puntos. En 7 de los 13 clones bajo estudio, la estabilidad del producto durante el almacenamiento a $85^{\circ} \mathrm{F}$. $\left(29.4^{\circ} \mathrm{C}\right.$.) fue comparable a la del control preparado de fruta silvestre. Los néctares de los clones 57-9-114 (Rico 18), 57-2-142 (Rico 19) y 57-2-51 (Rico 20) fueron clasificados como superiores al del control. La muestra correspondiente al clon 57-2-142 (Rico 19) obtuvo la evaluación más alta en pruebas organolépticas después de almacenada por 9 meses bajo las condiciones ya descritas. Esta muestra también obtuvo el segundo lugar entre los 13 clones en cuanto a su rendimiento de néctar.

\section{LITERATURE CITED}

1. Ballantine, R. Determination of Ascorbic Acid in Citrus Fruit Juices, Ind. and Eng. Chem. Anal. Ed. 1s(2): 89, 1941.

2. U.S. Department of Health, Education, and Welfare, Food and Drug Administration. Federal Register, 1964.

3. Official Methods of Analyses of the Association of Official Agricultural Chemists, 10th ed., Washington, D.C., 1965.

4. Peryam, D. R. and Pilgrim, F. J., Hedonic scale method of measuring food preferences, Food Tech. 11(9): 9-14, 1957.

5. Sánchez-Nieva, F., La Industrialización de Frutas Tropicales, Rev. de Agr. de P.R. 4 7(2): 197-210, 1960. 